\title{
KURIOS
}

(Jurnal Teologi dan Pendidikan Agama Kristen)

Vol. 3, No. 1, Oktober 2015 (48-65)

ISSN 2406-8306 (print)

http://www.sttpb.ac.id/e-journal/index.php/kurios

\section{Peran Orang Tua Dalam Menerapkan Kasih dan Disiplin Kepada Anak Usia 2-6 Tahun Sebagai Upaya Pembentukkan Karakter}

\author{
Vitaurus Hendra \\ Sekolah Tinggi Teologi Pelita Bangsa Jakarta
}

\section{Pendahuluan}

Kasih dan disiplin merupakan kebutuhan dasar setiap anak dalam upaya pembentukan karakter yang sehat. Kedua hal ini tidak dapat dipisahkan, demikian pula dalam penerapannya, kasih dan disiplin harus diterapkan secara seimbang. Kasih adalah alasan, motif dan tujuan adanya disiplin, dan disiplin merupakan perwujudan kasih itu sendiri.

Masalah yang dihadapi orang tua saat ini adalah orang tua terjebak ke dalam dua pilihan dalam menerapkan kasih dan disiplin, yaitu menerapkan kasih dan disiplin secara bersama-sama dan seimbang atau menerapkan salah satunya dan memisahkan yang lainnya. Hal ini terjadi akibat kesalahpahaman orang tua mengenai konsep relasi antara kasih dengan kebebasan serta disiplin dan hukuman. Konsep yang menyatakan bahwa disiplin sama dengan hukuman, membuat disiplin begitu sempit dan dipandang negatif, kejam serta tidak mencerminkan adanya kasih. Konsep inilah yang kemudian menciptakan konsep berikutnya, yaitu disiplin dan kasih adalah dua hal yang saling bertentangan sehingga orang tua terjebak pada penerapan kasih atau disiplin yang ekstrim.

Orang tua dapat memilih, mengasihi tanpa mendisiplinkan atau mendisiplinkan tanpa mengasihi. Pandangan ini tentu sangat bertentangan dengan apa yang diajarkan dalam kitab Amsal 13:24 "Siapa tidak menggunakan tongkat, benci kepada anaknya; tetapi siapa mengasihi anaknya, menghajar dia pada waktunya." Orang tua yang mengasihi anak pasti memberikan disiplin, sebaliknya orang tua yang tidak mendisiplinkan anak berarti membenci anaknya.

Penerapan kasih dan disiplin yang tepat dan proposional pada anak akan mempengaruhi karakter dan masa depan anak. Selain mengerti akan keterkaitan antara kasih dan disiplin, orang tua juga harus mengerti dan memahami karakteristik anak usia 2-6 tahun yang 
unik dan khas, sehingga dapat memainkan peranannya dengan tepat sebagai rangkap lingkup pertama dimana anak belajar dan bersosialisasi.

Hal ini didukung pula oleh Stephen Tong, beliau menyatakan ketika seseorang masih kanak-kanak, is memiliki kemungkinan yang sangat besar untuk kita (orang tua) bentuk. Pada usia inilah peran orang tua sebagai arsitek jiwa anak sangat penting. Untuk itu, penulis memilih usia 2-6 tahun sebagai tolak ukur keberhasilan para orang tua dalam membentuk karakter anak mereka.

\section{Kasih}

Menurut kamus bahasa Indonesia yang disusun oleh Hasan Alwi, kasih berarti perasaan sayang, sedangkan kasih sayang berarti cinta kasih dan belas kasihan. Tidak jauh berbeda dengan Hasan Alwi, W.J.S Poerwadarminta dalam Kamus Umum Bahasa Indonesia beliau mengartikan kasih dengan Merasa atau perasaan sayang dan belas kasihan. Dalam terjemahan bahasa Inggris, kata kasih (love) diartikan sebagai berikut: To have a deep-seated affection for Perasaan sayang yang mendalam; To having a liking or enthusiasm for Kesukaan atau kegembiraan yang besar.

Kata ini bermakna afektif berupa ungkapan yang paling dalam dari kepribadian atau kekuatan dari dalam diri pribadi yang mendorongnya untuk melakukan tindakan yang mendatangkan kegembiraan (kesukaan untuk melakukan hal-hal yang menggembirakan) dalam hubungan antar pribadi sekaligus pribadi paling akrab dan dekat berkaitan dengan orang tua kepada anak baik dalam bentuk fisik maupun verbal.

\section{Disiplin}

Dalam Kamus Umum Bahasa Indonesia disiplin berarti latihan batin dan watak dengan maksud supaya segala perbuatannya selalu menaati tata tertib. Dalam kamus bahasa Inggris disiplin berarti: "The establishing of correct order and behaviour with rules, training, etc. Penetapan tata tertib dan kebiasaan yang benar dengan aturan, pelatihan, dan lain sebaginya; A branch or subject of learning etc. Sebuah cabang atau subjek ilmu pengetahuan.

Makna kata disiplin ini adalah sebuah proses pemuridan/pendidikan anak yang dilakukan dengan terencana sebagai bentuk pencegahan, pengarahan dan pembentukan karakter yang positif.

\section{Karakter}

Penerjemahan kata karakter ke dalam bahasa Indonesia, ada dua kata yaitu sifat dan watak. Watak dalam bahasa Indonesia diartikan sebagai sifat batin manusia yang 
mempengaruhi pikiran dan tingkah lake ; budi pekerti; tabiat. Makna yang penulis maksudkan dalam tulisan ini lebih kepada "nilai manusia" atau kualitas diri yang membedakan satu manusia dengan manusia lainnya dan tampak dalam pikiran, perasaan dan tindakan manusia itu. Tujuan akhir dari semua ini adalah keserupaan dengan Kristus, sebagaimana dinyatakan Alkitab (Roma 8:29).

\section{Pembahasan}

\section{Kasih dalam Alkitab}

\section{Perjanjian Lama}

Kasih dalam Perjanjian Lama, baik yang insani maupun ilahi, adalah ungkapan yang paling dalam dari kepribadian sekaligus hubungan pribadi paling akrab dan dekat. Dalam arti non agamawi 'ahey'adalah kata yang paling umum digunakan untuk menggambarkan dorongan yang dirasakan oleh dua insan beda jenis kelamin, yang didalamnya tidak ada rasa pengekangan atau rasa najis. Kata ini juga digunakan untuk hubunganhubungan pribadi (Kejadian 22:2;37:3) dan sub-pribadi (Amsal 18:21) tanpa ada kaitannya dengan dorongan seksual.

Pada dasarnya kasih merupakan kekuatan dari dalam (Ulangan 6:5) yang mendorong untuk melakukan sesuatu tindakan yang mendatangkan kegembiraan (Amsal 20:13), memperoleh objek yang membangkitkan hasrat (Kejadian 27:4), atau dalam hal pribadi untuk melakukan pengorbanan diri demi kebaikan orang yang dikasihi (Imamat 19:18,34), dan ketaatan yang tulus (1 Samuel 20:17-42). Kasih merupakan ungkapan terdalam dari dalam diri seseorang yang mendorong orang tersebut untuk melakukan sesuatu yang mendatangkan kegembiraan walaupun harus berkorban.

\section{Perjanjian Baru}

Di dalam Perjanjian Baru terdapat 4 kata kasih, yaitu filia, eros, storge, dan agape. Ini adalah bentuk-bentuk kasih yang bisa ada di dalam diri manusia secara umum maupun yang sudah menjadi anak-anak Tuhan. Tetapi jika kasih-kasih tersebut tidak berpusat pada kasih agape, maka kasih-kasih ini dapat bersifat egois, kej am, dan manipulatif dalam relasi satu dengan yang lain.

Kata paling umum untuk semua bentuk kasih dalam Perjanjian Bani adalah agape, agapao. Kata agape dan agapao berarti kasih yang paling tinggi dan paling mulia, yang melihat suatu nilai talc terbalas pada objek kasihnya. Penggunaannya dalam Perjanjian Baru tidak langsung berasal dari bahasa Yunani klasik, tetapi lebih cenderung 
dari LXX, yang menerjemahkan 95\% kasih dalam bahasa Ibrani dengan kata itu, dan menggunakannya untuk menggambarkan kasih Allah kepada manusia, kasih manusia kepada Allah, dan kasih manusia kepada sesamanya. Berkenaan dengan pengasuhan orang tua, orang tua hendaknya mengasihi anaknya dengan talus, segenap hati, tidak pamrih, dan menerima anak apa adanya sebagaimana Allah juga mengasihi orang percaya saat mereka masih berdosa.

Kasih filia sering disebut sebagai brotherly love, yaitu kasih persahabatan di antara saudara, atau teman. Filia/ Fileo adalah pilihan lain ganti agapao. Kata ini digunakan untuk menggambarkan kasih yang akrab (Yohanes 11:13, 36; Wahyu 3:19), dan kesukaan untuk melakukan hal-hal yang menggembirakan (Matius 6:5). Kasih seperti ini jelas secara natural timbul dengan adanya interaksi antar individu yang positif, contohnya dengan saling berbicara, merasakan kecocokan, nyaman, sharing dan sebagainya. Akan tetapi jika kasih ini tanpa diterangi kasih agape, persahabatan yang terjalin sebenarnya akan menjadi sempit sekali. Perasaan yang ada seringkali hanyalah: `aku mengasihi engkau selama engkau masih setia, tidak merubah sikap, dan masih cocok dengan seleraku.' Kasih filia yang berdiri sendiri hanyalah suatu kasih yang egois, kejam dan mencengkeram.

Kasih eros diidentikkan sebagai romantic love, yakni perasaan yang terdapat di antara pasangan lawan jenis atau lovers. Kasih eros tanpa kasih agape akan menjadi kasih yang salah, ada kasih didalamnya tetapi hanya menjadi alat untuk memenuhi keinginan sepihak saja, misalnya hanya mau memenuhi kepuasan seksual.

Dalam Perjanjian Baal kata Yunani ems tidak terdapat untuk menyatakan kasih Allah atau kasih kepada Allah, ataupun kasih dalam persekutuan Kristen. Hal senada juga disampaikan James F. Childress dan John Macquarrie yang menuliskan " humans may not love God in the sense of eros." Demikian pula halnya dalam pengasuhan anak, orang tua tidak dapat menyatakan kasih eros kepada anaknya.

Kasih storge adalah motherly love (juga berlaku bagi ayah). Kasih ini adalah kasih yang penuh kebaikan, pengorbanan dan kesungguhan. Akan tetapi, jika kasih storge tidak diterangi kasih agape dalam relasi orangtua dan anak, maka kasih yang ada dapat bersifat subjektif, memanjakan atau memaksakan kehendak atas nama kasih. Seringkali orangtua berkata bahwa anak mereka harus menjadi orang yang pintar dan mengejar profesi yang tinggi. Pastinya, hal ini merupakan sesuatu yang baik bagi anak, dan orang tua berkorban serta berjuang supaya anak mereka dapat mencapai hal-hal tersebut. Akan tetapi hal ini menjadi salah karena terdapat unsur pemaksaan. Apa yang ada dalam pikiran orangtua 
belum tentu sesuai dengan karunia dan kemampuan yang diberikan Tuhan kepada sang anak. Tanpa kasih agape, kasih storge bisa menjadi salah dan tidak sesuai dengan kehendak Tuhan.

\section{Disiplin}

Secara etimologis, Disiplin berasal dari kata latin discipulus (murid). Dictionray.com menuliskan "discipline refers to systematic instruction given to a disciple. This sense also preserves the origin of the word, which is Latin disciplina "instruction", from the root discere "to learn," and from which discipulus "disciple, pupil" also derives. (disiplin mengacu pada instruksi sistematis yang diberikan kepada seorang murid. Hal ini sesuai dengan kata dasar/aslinya, yaitu bahasa Latin disciplina "instruksi" dari akar katadiscere "belajar" dan dari kata discipulus "murid"). Pendapat mengenai akar kata disiplin ini didukung pula oleh Ariesandi S. Beliau menuliskan bahwa kata disiplin berasal dari bahasa Latin, discipulus, yang berarti "pembelajar". Jadi, disiplin itu sebenarnya difokuskan pada pengajaran. Disiplin berkaitan dengan proses pembelajaran/ pemuridan, dimana anak menjadi murid/pelajar sedangkan orang tua adalah gurunya/pengajar.

Tujuan disiplin ini selalu berkaitan dengan aturan atau tata tertib, lebih menekankan penanaman norma. Anakanak dipandang sebagai objek didik yang hams dibentuk dan diarahkan untuk menaati setiap aturan di masyarakat, sehingga mampu menciptakan keteraturan sosial.

\section{Disiplin dari Sudut Pandang Alkitab}

Pentingnya disiplin dari sudut pandang alkitab dengan dua pendekatan yaitu disiplin sebagai ajaran alkitab dan disiplin sebagai bentuk kebutuhan manusia karena naturnya yang berdosa.

\section{Kasih dari Sudut Pandang Psikologis}

Kasih adalah kebutuhan (need) dasar anak. Anak memerlukan kasih tidak hanya pada masa pembentukannya saja, tetapi disepanjang hidup anak. Untuk itu orang tua hams dapat memenuhi kebutuhan anak akan kasih dan dapat dilakukan dengan sentuhan fisik, dekapan, pelukan, dan sanjungan. Kasih diberikan kepada anak dalam bentuk kontak fisik maupun verbal.

\section{Ajaran Alkitab}

Kitab Amsal menuliskan beberapa nats mengenai tugas orang tuauntuk mendisiplin anaknya, diantaranya Amsal 13:24; 19:18; 22:6; 22:15; 23:13; 29:15,17. Keseluruhan ayat 
ini menyatakan kepada orang tua betapa pentingnya menerapkan disiplin kepada anak. Dasar teologis akan pentingnya disiplin orang tua bagi anak, yaitu:

\section{Perintah Allah Bapa}

Allah Bapa senantiasa mendisiplinkan manusia ciptaanNya baik secara individual maupun kelompok dengan tujuan agar mereka taat, hormat clan takut kepada-Nya. Alkitab mengajarkan bahwa cara Tuhan mendisiplinkan umatNya sama seperti ayah mendisiplinkan anaknya (Ulangan 8:5; Mazmur 6:2;38:2-3) yaitu dengan cara memberi pengajaran, memberi teguran, menyatakan nasihat. Dengan kehendakNya, Ia juga mengizinkan terjadinya penderitaan seperti sakit penyakit, kerugian bahkan pembuangan ke tempat atau negeri lain.

\section{Perbuatan Yesus Kristus}

Tuhan Yesus Kristus juga menegakkan disiplin bagi murid-murid-Nya, dengan memberi contoh teladan dalam berbagai aspek kehidupan seperti dalam menggunakan uang, menggunakan waktu, hidup berdoa dengan tekun. Tuhan Yesus juga menyatakan agar murid-murid-Nya belajar hidup tertib dalam arti memelihara kesucian hidup agar senantiasa merasakan kehadiran Allah. Bagi Tuhan Yesus, orang dewasa hams mendisiplinkan anggota tubuhnya seperti tangan, kaki, mata dan anggota tubuh lainnya, agar tidak membawa keburukan bagi orang lain, terutama menyesatkan anak-anak dibawah asuhan mereka (Matius 18:8-10).

\section{Roh Kudus mengerjakan kedisplinan}

Alkitab mengajarkan bahwa Roh Kudus datang untuk menyatakan kebenaran ilahi bagi orang yang percaya kepada Yesus Kristus. Ia datang ke dunia untuk membuat orang insyaf akan dosa dan kejahatannya lalu berbalik kepada Sang Kebenaran yang memerdekakan yaitu Yesus Kristus (Yohanes 16:6-8, 11-13). Roh Kudus juga datang membuat orang memiliki hikmat hidup dan kekuatan batiniah agar dapat hidup sesuai kehendak Allah (Efesus 1;16,17; 3:16-18). Roh Kudus juga datang ke dalam hidup dan persekutuan orang percaya untuk memberikan kesaksian hidup bukan kekacauan (2 Timotius 1;7).

Semua Penjelasan ini menunjukkan bahwa Alkitab begitu gamblang menjelaskan bahwa disiplin diperlukan dalam kehidupan manusia, hal ini juga berarti disiplin sangat diperlukan dalam mendidik anak agar sesuai dengan kehendak Allah. Tuhan Yesus juga menyatakan agar murid-murid-Nya belajar hidup tertib dalam arti memelihara 
kesucian hidup agar senantiasa merasakan kehadiran Allah. Bagi Tuhan Yesus, orang dewasa harus mendisiplinkan anggota tubuhnya seperti tangan, kaki, mata dan anggota tubuh lainnya, agar tidak membawa keburukan bagi orang lain, terutama menyesatkan anak-anak dibawah asuhan mereka (Matius 18:8-10).

\section{Natur Manusia Berdosa}

Anak memiliki sifat orang berdosa dan secara alami akan tidak taat dan mengikuti jalan kebodohan dari pada jalan hikmat (Ams. 22:15). Alkitab mengajarkan perlunya perbaikan yang positif dan bahkan hukuman badan dengan sangat jelas sehingga orang tua yang menjalankannya dapat membacanya. Kitab Amsal menuliskan: "orang baik meninggalkan warisan bagi anak cucunya, tetapi kekayaan orang berdosa disimpan bagi orang benar; Siapa tidak menggunakan tongkat benci kepada anaknya; tetapi siapa mengasihi anaknya menghajar dia pada waktunya" (Amsal 13:22,24). "Hajarlah anakmu selama ada harapan, tetapi jangan engkau menginginkan kematiannya" (Amsal 19:18). "Jangan menolak didikan dari anakmu: is tidak akan mati kalau engkau memukulnya dengan rotan. Engkau memukulnya dengan rotan, tetapi engkau menyelamatkan nyawanya dari dunia orang mati" (Amsal 23:13-14)."Tongkat dan teguran mendatangkan hikmat, tetapi anak yang dibiarkan mempermalukan ibunya" (Amsal 29:15).

Jika hal ini benar pada masa Salomo, maka hal ini juga benar pada hari ini, karena natur manusia berdosa sama kapan pun dan di mana pun. Karena adanya bibit dosa dalam diri anak inilah maka dalam pendidikan anak perlu dikoreksi yaitu didisiplin.

\section{Disiplin dari Sudut Pandang Psikologis}

Disiplin merupakan suatu kebutuhan dasar setiap anak dalam rangka pembentukan dan pengembangan watak yang sehat. Paul.R. menuliskan: "Children who accept discipline will also learn how to instruct their own families." Penulis menerjemahkannya dengan anak-anak yang menerima disiplin juga akan belajar bagaimana mengajar keluarga mereka sendiri. Hal ini sesuai dengan tujuan pengajaran yang diberikan orangtua Umat Israel kepada anak-anaknya yaitu, siap untuk menikah dan mendirikan rumah tangga sendiri dan mengembangkan keterampilan kerja agar dapat membiayai dan mengurus rumah tangganya itu

\section{Menurut Para Ahli}

Menurut para ahli, disiplin identik dengan pendidikan. Disiplin dikaitkan dengan proses pendidikan, dimana orang tua sebagai pendidik dan anak sebagai objek didik. Berikut beberapa pendapat ahli pendidikan anak dalam mendefinisikan disiplin. Doni 
Koesoema A menyatakan: "kedisiplinan merupakan proses pengajaran, pelatihan, dan seni mendidik."1"Selaras dengan pandangan Komesky, Dr. Brazelton menyatakan bahwa disiplin berarti mendidik. Disiplin merupakan suatu proses pendidikan.

Menurut Paul Meier yang dikutip oleh S.B Sidjabat, disiplin merupakan kebutuhan dasar anak pada masa pembentukan(formative years). Meier menegaskan bahwa disiplin tidak identik dengan hukuman saja, tetapi juga mencakup pemberitahuan, penjelasan, dan pelatihan dalam hal-hal kebajikan." Disiplin tidak berfokus pada hukuman, tetapi jauh lebih luas daripada itu, disiplin merupakan suatu bentuk pendidikan jangka panjang yang bersifat konstruktif.

"Ariesandi menyatakan bahwa disiplin sesungguhnya adalah proses melatih pikiran dan karakter anak secara bertahap sehingga menjadi seseorang yang memiliki kontrol diri dan berguna bagi masyarakat".

\section{Disiplin dan Hukuman}

Disiplin dan hukuman bukanlah hal yang sama, hukuman merupakan bagian dari disiplin yang sehat, namun disiplin memiliki dimensi yang jauh lebih luas daripada sekedar hukuman. Ariesandi menjelaskan perbedaan mendasar antara disiplin dan hukuman sebagai berikut:

- Hukuman mengajarkan suatu pelajaran melalui pemak saan emosional atau kekerasan fisik. Hukuman mung kin terlihat bisa menghentikan perilaku yang tidak diinginkan saat ini namun sudah pasti tidak mencegah nya terulang lagi di masa mendatang.

- Disiplin menggunakan kebijksanaan untuk mengajar kan nilai-nilai yang memperlihatkan betapa seorang anak dapat menentukan sendiri pilihannya dengan baik sesuai dengan perkembangan emosi anak saat itu. Oleh karena itu, tidak ada "cara yang benar" yang dapat berfungsi sepanjang waktu dan untuk semua situasi.

\section{Karakter}

Secara etimologis, kata karakter berasal dari bahasa Yunani "karasso", yang berarti cetak biru, 'format dasar', 'sidik' seperti dalam sidik jari. Karakter adalah sesuatu yang tidak dapat dikuasai oleh intervensi manusiawi, seperti ganasnya laut dan gelombang pasang dan angin. Manusia tidak dapat memberi bentuk atasnya. Sama seperti 
bumi, manusia tidak dapat membentuknya sebab bumi memiliki karakter. Namun sekaligus, bumi itu sendirilah yang memberikan karakter pada realitas lain.

Terjadi ambiguitas terminologi karakter, dikatakan bahwa karakter adalah sesuatu yang tidak dapat diubah, tetapi sekaligus sesuatu yang dapat diubah. Untuk mengatasi ambiguitas terminologi karakter Mounier mengajukan dua cara interpretasi. Mounier melihat karakter sebagai dua hal, yaitu pertama, sebagai sekumpulan kondisi yang telah diberikan begitu saja, atau telah ada begitu saja, yang lebih kurang dipaksakan dalam diri individu. Karakter yang demikian dianggap sebagai sesuatu yang telah ada dari asalnya (given). Kedua, karakter juga dipahami sebagai tingkat kekuatan melalui mana seseorang individu mampu menguasai kondisi tersebut (given).

Karakter yang kedua ini disebut sebagai sebuah proses yang dikehendaki (willed). Istilah karakter didefinisikan oleh Webster's Dictionary sebagai "the aggregate features and traits that form the apparent individual naure of some person or thing; moral or ethical quality; qualities of honesty, courage, integrity; good reputation; an account of the qualities or peculiarities of a person or thing." Kalimat ini menjelaskan bahwa watak dapat diartikan sebagai keseluruhan kualitas ciri-ciri atau sifat khas moral etis, kejujuran, keberanian, reputasi baik dan integritas dari kehidupan seseorang.

Ensiklopedi Indonesia menegaskan bahwa watak merupakan "keseluruhan dari segala macam perasaan dan kemauan yang menampak keluar sebagai kebiasaan pada cara bereaksi terhadap dunia luar, dan pada ideal- ideal yang diidam-idamkan." Sebagai bandingan, Ensiklopedi Pendidikan mencatat bahwa watak adalah "struktur rohani yang tampak pada kelakuan dan perbuatan, dan terbentuk karena pembawaan dan pengaruh lingkungan." Dalam buku Membesarkan Anak dengan Kreatif, S.B.Sidjabat menyatakan bahwa watak adalah sikap batin yang mempengaruhi atau tampak dalam pikiran, perasaan dan perbuatan atau perilaku.

\section{Karakter dalam Perspektif Alkitab}

Dilihat dari pandangan Alkitab, pembentukan karakter menyerupai kristus merupakan kehendak Allah. Setelah orang percaya sungguh-sungguh kepada Kristus, hidup orang percaya itu hams sesuai dengan apa yang dituliskan dalam Firman Allah. Progresifitas kualitas orang percaya itu tampak dalam pernyataan Alkitab dalam Efesus 4:1-2 "... supaya hidupmu berpadanan dengan panggilan itu. Hendaklah kamu selalu rendah hati, lemah lembut, dan sabar. 
Tunjukkanlah kasihmu dalam hal sating membantu...." Juga dikemukakan dalam Efesus 4:17-18 "...jangan hidup lagi sama seperti orangorang yang tidak mengenal Allah dengan pikirannya yang sia-sia dan pengertiannya yang gelap, jauh dari persekutuan dengan Allah..." Alkitab mengajarkan agar orang percaya harus senantiasa mau dibentuk dengan membuang karakter yang buruk seperti marah, geram, melakukan kejahatan, fitnah dan kata-kata kotor (Kolose 3:5-11), disisi lain orang percaya juga hams belajar untuk memiliki belas kasihan, kemurahan, kerendahhatian, kelemahlembutan, dan kesabaran (3:1217). Karakter-karakter ini tidak lain adalah karakter Kristus yang nyata dalam diri orang percaya yang terus mengalami progresitas menyerupai kristus.

\section{Karakter dan Cara Belajar Anak}

Menurut pandangan psikologis yang mengikuti pikiran Jean Piaget dan Lawrence Kohlber, menegaskan bahwa karakter dapat diaj arkan kepada anak hanya dengan pendekatan kognitif. Prinsipnya, anak dijelaskan apa yang baik dan tidak, dikemukakan konsekuensinya, lalu dimampukan untuk memilih dan memutuskan. Teori ini menjelaskan bahwa dalam menanamkan karakter atau watak pada anak hams berkaitan dengan cara anak belajar. Anak belajar menggunakan panca indranya, artinya dalam mengajari anak mengenai karakter atau watak yang diinginkan harus melalui kegiatan yang dapat dilihat, didengar, dirasakan, dialami dan disentuh.

Kemudian pandangan teori belajar seperti Albert B andura menyatakan bahwa anak perlu melihat contoh atau teladan nyata dalam hidupnya atau contoh yang direkayasa (seperti film) tentang watak dan perangai yang baik. Diasumsikan bahwa jika anak melihat dan mengamati contoh atau teladan tokoh dalam waktu lama, anak akan mencenderungkan hatinya pada tokoh teladan dan akan termotivasi mengikutinya.

\section{Korelasi Antara Kasih, Disiplin dan Karakter}

\section{Kasih dan Disiplin}

Korelasi antara kasih dan disiplin akan terlihat sangat jelas dalam Amsal 13:24 yang menyatakan "Siapa tidak menggunakan tongkat, benci kepada anaknya; tetapi siapa mengasihi anaknya, menghajar dia pada waktunya." Alkitab mengarahkan orang ttia untuk mendisiplinkan anak-anak mereka dengan "tongkat" sepanjang masa pertumbuhan mereka.

Tongkat harus digunakan, yaitu tongkat orangtua, yang diarahkan dengan bijaksana dan kasih dan dirancang/ditujukan untuk kebaikan. Jadi, tidak ada alasan bagi orangtua untuk menjauhkan anak-anak mereka dari disiplin karena alasan kasih. Karena kasih tidak 
bertentangan dengan disiplin, kasih adalah motivasi, alasan dan tujuan disiplin, sedangkan disiplin adalah manifestasi dari kasih itu sendiri, hal ini dipertegas oleh BK. Narayan, bahwa disiplin merupakan kasih dalam bentuk ketegasan. Kasih dan disiplin saling mendukung dan melengkapi.

\section{Kasih, Disiplin dan Karakter}

Penerapan kasih dan disiplin pada anak-anak membentuk karakater anak. Karakter yang terbentuk akan sesuai dengan penerapan kasih dan disiplin yang terapkan, penerapan salah satunya secara berlebihan dengan mengesampingkan yang lainnya akan mengakibatkan karakter anak menjadi tidak seimbang dan kurang sehat. Sebaliknya, penerapan kasih dan disiplin yang benar dan tepat akan membentuk karakter yang sehat. Penerapan kasih tanpa disiplin akan membentuk karakter tidak taat pada otoritas, memberontak, dan sulit menentukan prioritas, sedangkan penerapan disiplin tanpa kasih akan menimbulkan akar pahit dan kebencian pada anak.

Untuk itu, orang tua harus dapat menerapkan kasih dan disiplin secara berimbang sehingga membentuk karakter yang sehat dan kuat. Jika kasih dan disiplin diterapkan secara berimbang kepada anak, maka akan timbul karakter mandiri, memiliki disiplin diri, percaya diri anak, bermoral dan memiliki pengendalian diri.

\section{Perkembangan Anak Usia 2-6 Tahun}

Penerapan kasih dan disiplin hams disesuaikan dengan perkembangan anak. Penerapan disiplin pada anak usia 2-6 tahun tentu akan berbeda dengan penerapan disiplin kepada anak usia 6-12 tahun, karena perkembangan anak usia 2-6 tahun tentu berbeda dengan anak usia 6-12 tahun, untuk itu orang tua harus memahami dan mengerti perkembangan anak usia 2-6 tahun, agar mampu menerapkan kedua kebutuhan penting ini yaitu kasih dan disiplin diterapkan dengan benar.

\section{Anak Ditinjau Secara Psikologis}

Menurut teori psikologi, seorang individu dikatakan sebagai anak jika individu mulai melewati masa bayi yang penuh ketergantungan, yakni kira-kira dua tahun sampai saat anak matang secara seksual, kira-kira tiga belas tahun untuk wanita dan empat belas tahun untuk pria.

Pada saat ini, secara luas diketahui bahwa masa anakanak dibagi lagi menjadi dua periode yang berbeda, awal dan akhir masa anak-anak. Periode awal berlangsung dari umur dua sampai enam tahun dan periode akhir dari enam sampai tiba saatnya anak matang secara seksual. 


\section{Ciri-Ciri Perkembangan Anak Usia 2-6 Tahun Perkembangan Fisik}

Perkembangan fisik menggambarkan perubahan penampilan fisik seorang anak. Perkembangan fisik atau jasmani merupakan proses yang berlangsung secara kontinu. Perkembangan fisik memungkinkan seorang anak untuk dapat lebih mengembangkan keterampilan fisik dan eksploriasi terhadap lingkungannya tanpa bantuan orang lain.

Selama masa anak-anak awal, pertumbuhan fisik berlangsung lambat dibandingkan dengan tingkat pertumbuhan selama masa bayi. Meskipun selama masa anak-anak pertumbuhan fisik mengalami perlambatan, namun ketrampilanketrampilan motorik kasar dan motorik halus justru berkembang pesat. Selama masa anakanak awal, tinggi rata-rata anak bertambah 2,5 inci dan berat bertambah 2,5 hingga 3,5 kg tiap tahunnya. Pada usia 3 tahun, tinggi anak sekitar 38 inci dan beratnya sekitar 16,5 kg. Pada usia 5 tahun, tinggi anak mencapai 43, 6 inci dan beratnya 21, $5 \mathrm{~kg}$.

Ada 3 kemungkinan poster tubuh pada anak, ada yang berpostur gemuk lembek (endomorfik), ada yang kuat berotot (mesomorfik), dan ada pula yang relatif kurus (ektomorfik). Dalam usia ini otot-otot anak menjadi lebih kuat dan tulangtulang tumbuh menjadi lebih besar dan keras. Selain menjadi lebih besar dan keras, otot anak juga menjadi lebih berat, sehingga anak tampak lebih kurus tetapi beratnya bertambah.

Gigi anak usia ini masih merupakan gigi susu dan akan berganti pada perkembangan berikutnya menjadi gigi tetap. Bila masa awal kanak-kanak ini berakhir, pada umumnya anak akan memiliki satu atau dua gigi tetap di depan dan beberapa celah di mana gigi tetap akan muncul.

Perkembangan fisik yang sangat penting selama masa anak-anak awal ialah perkembangan otak dan sistem saraf. Meskipun otak tents bertambah pada masa awal anak-anak, namun pertumbuhannya tidak sepesat pada masa bayi. Pada saat bayi mencapai usia 2 tahun, ukuran otaknya rata-rata $75 \%$ dart otak orang dewasa, dan pada usia 5 tahun, ukuran otaknya telam mencapai $90 \%$ otak orang dewasa. Jadi selama 3 tahun masa awal anak-anak, yaitu usia 2 sampai 5 tahun otak anak hanya berkembang sebanyak 15\% saja.

\section{Perkembangan Motorik}

Dengan bertambah matangnya perkembangan otak yang mengatur sistem syaraf-otot (neuromuskuler) memungkinkan anak-anak usia ini lebih lincah dan aktif bergerak. Dengan meningkatnya usia nampak perubahan dari gerakan kasar mengarah ke gerakan yang lebih halts yang memerlukan kecermatan dan kontrol otot-otot yang lebih 
halus serta koordinasi. Banyak kemampuan fisik yang dikembangkan secara motorik yang dikembangkan anak pada usia ini, antara lain dapat berjalan dengan stabil, mampu berlari, menaiki tangga, melompat, menendang dan melemparkan sesuatu seperti bola atau menangkap bola yang dilemparkan kearahnya, serta menarik dan mendorong, merobek, memotong sesuatu. Anak juga belajar memegang pensil dan berupaya menggambar di kertas dalam rangka melatih koordinasi mata, otot, tangan dan pikirannya.

\section{Perkembangan Inteligensi (Kognitif)}

Seiring dengan meningkatnya kemampuan anak untuk mengeksplorasi lingkungan, karena bertambah besarnya koordinasi dan pengendalian motorik yang disertai dengan meningkatnya kemampuan untuk bertanya dengan menggunakan kata-kata yang dapat dimengerti oleh orang lain, maka dunia kognitif anak berkembang pesat, makin kratif, bebas, dan imanjinatif.

\section{Perkembangan Bahasa}

Perkembangan bahasa merupakan basil perkembangan simbolisasi. Dengan demikian pada masa ini anak-anak telah mengalami sejumlah nama-nama dan hubungan antara simbol-simbol. Hal ini sejalan dengan pemikiran B.S. Sidi abat, beliau menjelaskan bahwa kemampuan berbahasa lisan anak berkembang dengan pesat pada usia anak-anak awal selain oleh karena pematangan organ-organ bicara dan fungsi berpikir, juga disebabkan lingkungan yang ikut membantu mengembangkannya. Kosakata anak bertambah dari 300 hingga 1.200 seiring dengan kemampuannya untuk mendengar, menyimak dan menirukan kata yang diucapkan oleh orang tua, kakak dan teman-temannya.

Menurut Elizabeth B. Hurlock hal ini disebabkan karena dua hal, yaitu:

Belajar bicara merupakan sarana pokok dalam sosialisasi. Anak-anak yang lebih mudahberkomunikasi dengan teman sebaya akan lebih mudah diterima sebagai anggota kelompok daripada anak yang kemampuan berkomunikasinya terbatas.

Belajar berbicara merupakan sarana untukmemperoleh kemandirian. Anak- anak yang tidak dapat mengemukakan keinginan dan kebutuhannya, atau tidak dapat berusaha agar dimengerti orang lain cenderung diperlakukan sebagai bayi dan tidak berhasil memperoleh kemandirian yang diinginkan.

\section{Perkembangan Afektif (Emosi)}

Pada usia 4 tahun, anak sudah mulai menyadari akunya (dirinya), bahwa akunya 
berbeda dengan bukan aku (orang lain atau benda). Kesadaran ini diperoleh dari pengalamannya, bahwa tidak setiap keinginannya dipenuhi oleh orang lain atau benda lain. Anak menyadari bahwa keinginannya berhadapan dengan keinginan orang lain, sehingga orang lain tidak selamanya memenuhi keinginannya. Bersamaan dengan itu, berkembang pula perasaan harga diri yang menuntut pengakuan dari lingkungannya.

Jika lingkungannya (terutama orang tua) tidak mengakui harga diri anak, seperti memperlakukan anak secara keras, atau kurang menyayangi anak, maka pada diri anak akan berkembang sikap-sikap: (a) keras kepala/dua hal, yaitu: Belajar bicara merupakan sarana pokok dalam sosialisasi. Anak-anak yang lebih mudah berkomunikasi dengan teman sebaya akan lebih mudah diterima sebagai anggota kelompok daripada anak yang kemampuan berkomunikasinya terbatas.

Belajar berbicara merupakan sarana untuk memperoleh kemandirian. Anak- anak yang tidak dapat mengemukakan keinginan dan kebutuhannya, atau tidak dapat berusaha agar dimengerti orang lain cenderung diperlakukan sebagai bayi dan tidak berhasil memperoleh kemandirian yang diinginkan.

\section{Perkembangan Sosial}

Salah sate tugas perkembangan masa awal anak-anak yang penting adalah memperoleh latihan dan pengalaman pendahuluan yang diperlukan untuk menjadi anggota "kelompok" dalam akhir masa anak-anak. Tanda-tanda perkembangan sosial pada tahap ini adalah:

- Anak mulai mengetahui aturan-aturan, baik di lingkungan keluarga maupun dalam lingkungan bermain.

- Sedikit demi sedikit anak mulai tunduk pada peraturan

- Anak mulai menyadari hak atau kepentingan orang lain

- Anak mulai dapat bermain bersama anak-anak lain, atau teman sebaya.

\section{Perkembangan Moral}

Perkembangan moral pada masa masa anak-anak awal masih dalam tingkat yang rendah. Hal ini disebabkan karena perkembangan intelektual anak-anak belum dapat mempelajari atau menerapkan prinsip-prinsip abstrak tentang benar dan salah.

Perkembangan moral anak dapat berlangsung melalui beberpa cara, sebagai berikut: 
- Pendidikan langsung, yaitu melalui penanaman pengertian tentang tingkah laku yang benar dan salah, atau baik dan buruk oleh orangtua, guru atau orang dewasa lainnya.

- Identifikasi, yaitu dengan cara mengidentifikasi atau menilai penampilan atau tingkah laku moral seseorang yang menjadi idolanya.

- $\quad$ Proses coba-coba, yaitu dengan cara mengembangkan tingkah laku moral secara coba-coba. Tingkah laku yang mendatangkan pujian atau penghargaan akan terus dikembangkan, sementara tingkah laku yang mendatangkan hukuman akan dihentikan.

\section{Perkembangan Kepribadian}

Berdasarkan teori Osmald Kroh maka masa anak-anak awal disebut masa trotzalter, periode perlawanan atau masa krisis pertama. Krisis ini terjadi karena ada perubahan yang hebat dalam diri anak, yaitu anak mulai menyadari aku-nya, anak menyadari bahwa dirinya terpisah dari lingkungan atau orang lain. Dengan kesadaran ini anak menemukan bahwa ada dua pihak yang sating dan terus akan berhadapan yaitu aku-nya dan orang lain. Anak mulai menemukan bahwa tidak setiap keinginannya dipenuhi oleh orang lain, memperhatikan kepentingannya. Pertentangan antara kemauan diri dan tuntutan lingkungannya, dapat mengakibatkan ketegangan dalam diri anak, sehingga tidak jarang anak meresponnya dengan sikap membandel atau keras kepala.

Di masa anak anak awal kepribadian anak sedang bergerak dari sikap dependen ke independen. Dalam diri anak, dorongan untuk mencoba dan melakukan sendiri apa yang dikehendaki sangat kuat ditambah lagi dengan cara berpikirnya yang terpusat, anak akan sangat sulit untuk dialihkan perhatiannya. Hal yang sebenarnya terjadi ialah bahwa pada masa anak-anak awal ini sedang terjadi pertunibuhan otonomi atau kemandirian yang sehat. Anak belajar untuk melakukan apa yang pernah anak lihat dari orang-orang dewasa disekitarnya.

\section{Pemenuhan Kasih Dan Disiplin Pada Anak}

Seperti yang sudah dikatakan diawal bahwa kasih dan disiplin merupakan kebutuhan dasar setiap anak dalam upaya pembentukan karakter yang sehat maka peran orang tua dalam memenuhi kasih dan disiplin pada anak sangatlah penting. Bagian berikut ini akan menjelaskan peran orang tua dalam menerapkan kedua kebutuhan ini. 


\section{Penerapan Kasih}

Dalam menerapkan kasih orangtua harusnya bijaksana dalam memberikan kasih kepada anak-anakya, jangan membabi buta. Stephen tong dalam bukunya Arsitek Jiwa I menyatakan bahwa seseorang yang mencintai orang lain secara membabi buta dan terlalu berlebihan, akan mengakibatkan objek cinta rusak. Kasih adalah baik, yang membuat kasih itu berdampak baik atau buruk ialah ketepatan dalam penerapannya.

Bentuk-bentuk pemenuhan kebutuhan kasih yang dapat digunakan orang tua, antara lain:
a) Kata-kata Pendukung
b) Hadiah
c) Layanan
d) Sentuhan Fisik
e) Waktu Berkualitas

\section{Penerapan Disiplin}

\section{Penerapan Disiplin Pada Anak Usia 2-6 Tahun}

Berdasarkan sifat dan peranan orang tua dan anak dalam disiplin, penulis berpandangan bahwa disiplin yang baik adalah disiplin yang positif yang membangun harga diri anak dan demokratis dengan memberikan peraturan yang didalamnya terdapat aturan, hukuman dan pujian. Perlu diingat bahwa peranan disiplin ialah mengontrol, mengendalikan dan mengarahkan kehendak anak. Ketiga unsur dalam disiplin demokratis yaitu aturan, hukuman dan pujian/hadiah akan sangat mendukung pengembangan kehendak anak kearah yang lebih baik.

\section{Penerapan Kasih dan Disiplin serta Implikasinya terhdap Karakter Anak}

Kasih dan disiplin yang diberikan pada anak dalam upaya penanganan kehendak akan membentuk karakter anak. Buah dari pembentukan kehendak masa anak-anak awal akan berdampak bagi kehidupan anak dimasa selanjutnya. Secara garis besar, karakter awal yang terbentuk dalam diri anak jika kasih dan disiplin diterapkan secara seimbang yaitu:

1. Mandiri

2. Memiliki disiplin diri

3. Membangun Percaya diri anak/perkembangan harga diri

4. Bermoral

5. Memiliki Pengendalian diri (self control) 


\section{Peran Orang Tua Dalam Menerapkan Kasih dan Disiplin}

Ada 3 peran yang hams diperankan dengan baik oleh orang tua, yaitu peran sebagai penyelidik, petani dan arsitek. Peran orang tua sebagai penyelidik bertujuan untuk menemukan apa yang tersembunyi atau belum diketahui. Peran orang tua disini adalah mengenali diri, keunikan, talenta, bakat dan karakter anak agar orang tua dapat membimbing, mendorong, dan membantu perkembangan anak dengan efektif.

Peran orang tua sebagai petani adalah mendorong anak agar dapat bertumbuh dan berkenibang menjadi dewasa dan berguna bagi masyarakat. Seorang petani menganggap setiap tanaman adalah unik. Petani tidak memaksakan kentang menjadi apel. Demikian pula, orang tua yang bertindak sebagai petani menganggap setiap anak adalah unik dan membantu perkembangan anak supaya menjadi dewasa dan berguna. Selain itu, petani tabu bahwa keberhasilannya dalam menumbuhkan basil yang baik merupakan basil kerjasama antara petani dan Sang Pencipta. Orang tua perlu memahami bahwa orang tua harus bekerja sama dengan Tuhan. Anak hams dibacakan kebenaran Firman Tuhan, diberi pendidikan iman yang baik, sekolah minggu dan doa. Ingat! Orang tua hanya mengusahakan tetapi Roh Kuduslah yang bekerja menumbuhkan iman anak.

Sedangkan sebagai arsitek, peran orang tua adalah pemberi dan penyalur nilai, menentukan apa yang benar dan salah, baik dan buruk, serta apa yang boleh dan yang tidak. Orang tua harus dapat memainkan 3 peranan ini sekaligus. Pertama sebagai teladan (arsitek), membangun komunikasi yang positif, efektif dan berkesinambungan (penyelidik, petani, dan arsitek), dan menjadi motivator dan facilitator (petani). Ketiga peran ini saling berkaitan dan mendukung. Selain itu peran penting yang juga hams dimainkan orang tua dalam mendidik anaknya ialah menjadi imam bagi anakanaknya, orang tua harus ingat bahwa karakter itu dimulai dari perjumpaan anak dengan pribadi Kristus, untuk itu orang tua harus membawa anak kepada Kristus sejak usia dini.

\section{Kesimpulan}

Dalam menghadapi perkembangan jaman yang semakin sarat dengan kemajuan IPTEK, anak tidak hanya butuh persiapan secara kognitif saja tetapi juga karakter. Untuk itu keluarga sebagai lingkungan primer dalam pembentukan karakter anak, hams berperan maksimal dalam membentuk anak yang berkarakter sehat dan kuat, terutama pada usia 2-6 tahun yang merupakan usia pembentukan anak (fin-waive year) karena pada usia ini anak masih sangat mudah untuk dibentuk. 
Salah satu aspek yang harus diperhatikan orang tua dalam pembentukan karakter adalah penerapan kasih dan disiplin pada anak. Kasih dan disiplin harus diterapkan secara berimbang, bijaksana dan disesuaikan dengan karakteristik anak. Pemberian kasih dan disiplin pada anak usia 2-6 tahun tentu akan berbeda dengan peniberian kasih dan disiplin pada anak usia 12-17 tahun. Untuk itu orang tua harus memahami tahap-tahap perkembangan anak.

\section{Daftar Pustaka}

Anonimus, Ensikloped' Alkitab Hasa Kizzi, Cetakan ke-6, Jakarta: Yayasan Komunikasi Bina Kasih/OMF, 2000

Anonimus, Perjanjian Lama, Ibrani-Indonesia, Jakarta: LAI, 2002

Anonimus, Alkitab Pent/11111ln Hidtp Berkelimpahan, Malang: Gandum Mas, 1994

Ariesandi S., CHt, Rahasia Mendidik Anak Agar Sukses dan Bahagia, Jakarta: PT. Gramedia Pustaka Utama, 2008

BK. Narayan, Anak Cerdas, Yogyakarta: Mediailmu, 2009

BS. Sidjabat, Membesarkan Anak Dengan Kreatif, Yogya karta: ANDI offset, 2008

Desmita, Psikologi Perkembangan, Cetakan 1, Bandung: Rosdakarya, 2005

Doni Koesoema.A,Pendidikan Karakter, Jakarta: PT. Grame dia Pustaka utama, 2007

Hasan Alwi, Kal111IS besar bahsa Indonesia, Edisi ketiga, Jakarta: Balai pusataka, 2001

H. Norman Wright, Menjacli Orang Tua yang Bijaksana, Yongyakarta: ANDI, 1996

Kamm Singkat Ibrani-Indonesia, Jakarta: BPK. Gunung Mulia, 1997

LAI, Alkitab, Jakarta: LAI, 2007

Mary Setiawani dan Stephen Ton. Seni Membentuk Karakter Kristen, Surabaya: LRII, 2005

Reni Akbar-Hawadi, Psikologi Perkembangan Anak, Cetakan ke-6, Jakarta: Grasindo, 2006

Sri Edti Wuryani Djiwandono, Psikologi Pendidikan, Cetakan ke-1, Jakarta : Gramedia, 2002

Singgih D. Gunarsa dan Yulia Singgih D.Gunarsa, Psikologi Praktis: Anak, Remaja dan Keluarg-a, Jakarta: BPK Gunung Mulia, 2000

Singgih D. Gunarsa dan Yulia Singgih D. Gunarsa, Psikologi Perkembangan Anak dan Remaja, Cetakan ke-12, Jakarta: BPK Gunung Mulia, 2006

Steve Chalke, Kiat Menjadikan Anak Ancla Sukses dan Bahagia., Cetakan ke-5, Yogyakarta: ANDI offset, 2009

T. Berry Brazelton, M.D. dan Joshua D. Sparrow, M.D, Disiplin Anak, (Jakarta: BIP, 2009).

Thomas W. Phelan, 1-2-3 Magic Cara Ajaib Mendisiplinkan Anak Umur 2-12 Tabun, (Yogyakarta: Andi, 2004).

W.J.S Poerwadarminta, Kanius Unnun Bahasa Indonesia, Cetakan ke-16 (Jakarta: Balai Pustaka, 1999).

W.R.F. Browning, Karnes Alkitab, (Jakarta: BPK, 2002).

W. Stanley Heath, Teologi Pendidikan Anak, Cetakan pertama, (Bandung: Yayasan Kalam Hidup, 2005).

Yopie Tjahjadi, Diktat Penibinaan Warga Gereja, (Jakarta: ITPPB, 2007).

http://www.akpermuhmks.ac.id/ http://dheeazz.blogspot.com/2009/12/peran-orang-tua-danmotivasi-belajar.html. 